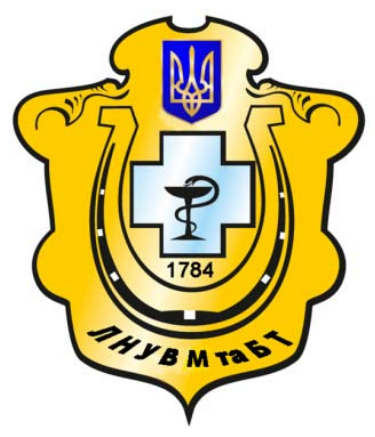

Науковий вісник Львівського національного університету ветеринарної медицини та біотехнологій імені С.3. Гжицького

Scientific Messenger of Lviv National University of Veterinary Medicine and Biotechnologies named after S.Z. Gzhytskyj

doi:10.15421/nvlvet7309

ISSN 2518-7554 print

ISSN 2518-1327 online

$\underline{\text { http://nvlvet.com.ua/ }}$

УДК 636.597:612:616.995.1-084

\title{
Вплив маклеї серцевидної на стан системи антиоксидантного захисту організму качок за дегельмінтизації фенбендазолом
}

\author{
I.О. Жукова, Н.О. Баздирєва, Н.I. Лонгус \\ patfiz@zoovet.kh.ua
}

Харківська державна зооветеринарна академія,

вул. Академічна, 10, смт. Мала Данилівка, Дергачівський район, Харківська обл., 62341, Україна

\begin{abstract}
Упровадження екологічних, безпечних для людей і тварин біопрепаратів є запорукою поліпшення якості життя. Заміна синтетичних антибіотиків, гормональних стимуляторів та інших небезпечних для здоров'я хіміопрепаратів природніми речовинами рослинного походження є ефективним кроком у зниженні кількості розладів травного тракту $і$ покращенні показників зростання і розвитку різних видів тварин. Сприятливий вплив цих препаратів пояснюється потенціалом даних речовин у підтримиі корисної мікрофлори травного тракту, яка захищає тварину від патогенних бактерій $і$ пом'якщує перебіг стресових періодів. У статті наведені дані досліджень стану антиоксидантної системи качок за застосування антигельмінтику фенбендазолу та маклеї сериевидної окремо та у комплексі. Експериментами доведено, ше задавання качкам тільки фенбендазолу призводило до активації процесів перекисного окиснення ліпідів, щчо проявлялось зниженням активності каталази і супероксиддисмутази (СОД), а також антиоксидантної активності (АОА) крові, щзо вказує на недостатність потенціалу власних ресурсів антиоксидантної системи (АОС) дослідної птиці.

Додавання рослинної добавки маклеї сериевидної окремо та одночасно з фенбендазолом призводило до індукиії антиокиснювальних ресурсів у організмі дослідних качок, щз характеризувалось у першому випадку зберіганням рівнів продуктів ПОЛ за рахунок індукованої активаџї̈ обох антиоксидантних ферментів та відновлення пулу ендогенної загальної АОА, а у другому випадку - зниженням до фізіологічної норми активності каталази та компенсаторного посилення активності СОД поряд із ростом загальної АОА.
\end{abstract}

Ключові слова: качки, каталаза, супероксиддисмутаза, тіобарбітурова кислота, антиоксидантна активність, дієнові кон'югати, малоновий діальдегід, антиоксидантна система.

\section{Влияние маклеи сердцевидной на состояние системы антиоксидантной защиты организма уток при дегельминтизации фенбендазолом}

\author{
И.А. Жукова, Н.А. Баздырева, Н.И. Лонгус \\ patfiz@zoovet.kh.ua
}

Харьковская государственная зооветеринарная академия,

ул. Академическая, 10, пгт. Малая Даниловка, Дергачевский район, Харьковская обл., 62341, Украина

Внедрение экологических, безопасных для людей и животных биопрепаратов является залогом улучшения качества жизни. Замена синтетических антибиотиков, гормональных стимуляторов и других опасных для здоровья химиопрепаратов натуральными веществами растительного происхождения, является эффективным шагом для снижения количества желудочно-кишечных расстройств и улучшения показателей роста і развития разных видов животных. Положительное воздействие этих препаратов объясняется потенциалом данных веществ в поддержке полезной микрофлоры желудочнокишечного тракта, которая защищает животное от патогенных бактерий и смягчает течение стрессовых периодов.

В статье приведены данные исследований состояния антиоксидантной системы уток при применении антигельминтика фенбендазола и маклеї сердиевидной отдельно и в комплексе. Эксперименты показали, что дача уткам только фен-

\section{Citation:}

Zhukova, I.O., Bazdyreva, N.O., Longus, N.I. (2017). Impact of macleay cordata on the state of antioxidant protection system of ducks at dehelmintization by phenbendazole. Scientific Messenger LNUVMBT named after S.Z. Gzhytskyj, 19(73), 40-45. 
бендазола приводило к активации прочессов перекисного окисления липидов, что проявлялось снижением активности каталазы и супероксиддисмутазы (СОД), а также антиоксидантной активности (АОА) крови, что свидетельствует о недостаточности потенциала собственных ресурсов антиоксидантной системы (AOC) опытной птиць.

Добавление растительной добавки маклеи сердиевидной отдельно и одновременно с фенбендазолом приводило к индукиии антиокислительных ресурсов в организме опытных уток, что характеризовалось в первом случае сохранением уровня продуктов ПОЛ за счет индуциированной активации обоих антиоксидантных ферментов и восстановления пула эндогенной общей АОА, а во втором - снижением до физиологической нормы активности каталазы и компенсаторного усиления активности СОД наряду с ростом общей АОА.

Ключевые слова: утки, каталаза, супероксиддисмутаза, тиобарбитуровая кислота, антиоксидантная активность, диеновые конъюгаты, малоновый диальдегид, антиоксидантная система.

\title{
Impact of macleay cordata on the state of antioxidant protection system of ducks at dehelmintization by phenbendazole
}

\author{
I.O. Zhukova, N.O. Bazdyreva, N.I. Longus \\ patfiz@zoovet.kh.ua \\ Kharkov state zooveterinary academy, \\ Akademichna Str., 1, Mala Danylivka, Kharkiv region, Dergachi district, 62341, Ukraine
}

The use of biological products ecologically safe for human and animals is the key to improve the quality of life. The replacement of synthetic antibiotics, hormone stimulants and other hazardous chemical drugs by natural substances of plant origin is an effective step to decrease gastrointestinal disorders and to improve the indices of growth and development of various species of animals. The beneficial effect of the above drugs can be explained by the potential of these substances to maintain beneficial microflora of gastrointestinal tract that protects the animal from pathogenic bacteria and softens the course of stressful periods.

The article presents the data on the research of the state of antioxidant system of ducks when the antihelmintic drug phenbendazol and Macleay cordata were used separately and in the combination. The experiments have shown that the use of only phenbendazole for ducks led to the activation of the processes of lipid peroxidation that was manifested by the decrease in the activity of catalase and superoxide dismutase (SOD) as well as antioxidant activity (AOA) of blood that proves the lack of the potential of own resources of antioxidant system (AOS) in the experimental birds. The addition of the herbal supplement of Macleay cordata separately and simultaneously with phenbendazole resulted in the induction of antioxidant resources in the body of the examined ducks that was characterizes in the first case by the storage of the levels of LPO products due to the induced activation of both antioxidant enzymes and the restoration of the pool of the endogenous total AOA, and in the second case, by the reduction to the normal physiological activity of catalase and compensatory increase in the activity of SOD alongside with the increase in the total antioxidant activity.

Key words: ducks, catalase, superoxide dismutase, thiobarbiturate acid, antioxidant activity, dien conjugates, malonic dialdehyde, antioxidant system.

\section{Вступ}

Птахівництво - це одна із найбільш інтенсивних галузей сільського господарства, яка також має ряд проблем пов'язаних із заразними хворобами, в тому числі і паразитарними. Однією з проблем протипаразитарних заходів є висока резистентність паразитів до антигельмінтних препаратів та токсичний вплив самих препаратів на організм людини і тварин. Погляди науковців на проблему вивчення потенційних ризиків отруєнь біотичної або ксенобіотичної етіології мають традиційний характер, та обмежуються визначенням у біологічних об'єктах низки класичних токсикобіохімічних тестів (оцінювання функціонального стану печінки, системи гемопоезу тощо).

Ці пропуски доповнює теперішня цитотоксикологія, яка вказує на те, що в основі цитотоксичних ефектів будь-якого потенційного токсиканту лежить окиснювальний стрес і запальні реакції. Відомо, що цитоплазматична мембрана ушкоджується у першу чергу, так як вона слугує бар'єром між поза- та внутрішньоклітинним оточенням, що забезпечує селективний транспорт речовин. Активні метаболіти кисню, які належать до класу найбільш реакційно активних, вважають високотоксичними, здатними ушкоджувати клітинні системи та їх біомембрани через окиснюва- льну деградацію ліпідів, білків, ДНК і РНК за вільнорадикальним механізмом, тому, навіть невеликі кількості продуктів, зокрема, ліпопероксидації будуть впливати на експресію генів, репараційні, метаболічні та біосинтетичні процеси (Zenkov et al., 2001; Garcon, 2006; Gutyj et al., 2016; Khariv et al., 2016; Lavryshyn et al., 2016; Martyshuk et al., 2016; Hariv and Gutyj, 2016; Nazaruk et al., 2016).

Фенбендазол (5-феніл-тіо-2-бензімідазолкарбамат), як найменш токсичний із похідних бензімідазолів $є$ досить ефективним препаратом для знищення паразитів різних класів і тому його було використано у наших дослідженнях.

Другим компонентом комплексної терапії $є$ препарати, які підвищують ефективність антигельмінтиків та усувають їх негативний вплив. У цьому ракурсі розглянуто застосування трави маклеї серцевидної або бокконії серцелистої (лат. Macleáya cordáta $R$. $B r) \quad$.3 iï відомими фітобіотичними властивостями. Маклея серцевидна вид багаторічних трав'яних отруйних рослин роду Маклейя (Macleaya) сімейства Макові (Рapaveraceae), яка розповсюджена у Східному Китаї і Японії, але іiі вирощують у промислових масштабах у Криму. Сировиною $є$ трава у якій максимальний вміст алкалоїдів накопичується на третій рік i вміст їх становить від 0,7 до $2 \%$ (Blinova and 
Jakovlev, 1990). Трава вміщує ізохінолінові алкалоїди, основні з яких - сангвінарин і хелеритрин. ІІЇ використовують у якості лікарської сировини для отримання алкалоїдного антимікробного препарату «Сангвіритрин», який застосовують для лікування уражень шкіри і слизових оболонок та інфікованих виразок і ран, що довго не загоюються (Zhukova et al., 2016).

Метою роботи є дослідження стану антиоксидантної системи качок за застосування фебендазолу та маклеї серцевидної окремо та у комплексі.

\section{Матеріал і методи досліджень}

У досліді використали 27 мускусних качок, які належать КП «Харківський зоопарк». Птиця віком 2 місяці, масою 1-1,5 кг була розділена на 5 дослідних $(\mathrm{n}=35)$ і 1 контрольну групу $(\mathrm{n}=7)$. Качки II групи одержували фенбендазол 22\% у дозі 50 мг/кг маси, III, IV i V групи отримували добавку меленої трави маклеї серцевидної у дозі 1,125, 11,25 і 0,563 г/кг корму відповідно. VI групі задавали комплекс із фенбендазолом (50 мг/кг м.т.) і маклеї серцевидної (1,125 г/кг корму). Дози трави маклеї серцевидної розраховували користуючись інструкцією із застосування німецького препарату «Сангровіт Extra» для свійської птиці, який вміщує 75\% трави маклеї. Контрольній (І групі) препарати не задавали. Дослідження проводили на 7, 14 i 21 добу після введення препарату. Інтенсивність процесів перекисного окиснювання ліпідів (ПОЛ) оцінювали за визначення у плазмі крові концентрації його продуктів - дієнових кон'югатів (ДК) і малонового діальдегіду (МДА) - у гептан-ізопропанольних екстрактах із використанням методики Гаврилової В.Б. і Мішкорудної M.I. (1985) (Gavrilova and Mishkorudnaja, 1985; Stehnii et al., 2007).

Рівень показників антиокиснювальної системи (АОС) досліджували за активністю каталази
(КФ 1.11.1.6) 3 використанням $\mathrm{H}_{2} \mathrm{O}_{2}$ спектрофотометрично (SHIMADZU UV-1800, Японія) за довжини хвилі 410 нм та активністю супероксиддисмутази (СОД; КФ 1.15.1.1) за визначенням гальмування відновлення безбарвних солей тетразолію супероксидними аніон-радикалами фотометрично (Koroljuk, 1988; Stehnii et al., 2007). Рівень загальної антиокислювальної активності (АОА) ліпідів, екстрагованих 3 плазми крові, визначали за ступенем їх здатності гальмувати накопичення ТБК-активних продуктів ПОЛ за інкубації суспензії жовткових ліпопротеїдів, який реєстрували спектрофотометрично (SHIMADZU UV1800, Японія) за довжини хвилі 535 нм, виражаючи АОА ліпідів плазми крові у відсотках (\%) інгібіції окиснення жовткових ліпопротеїдів (Klebanov, 1988; De Bono, 1994).

Результати досліджень оброблені статистично 3 використанням пакета програм Microsoft Excel 2003 (for Windows XP), вірогідність отриманих даних оцінювали за критерієм Ст'юдента.

\section{Результати та їх обговорення}

Протягом досліду у птиці не відзначено клінічних ознак отруєння.

Дослідженнями інтенсивності процесів ПОЛ у плазмі крові дослідних качок встановлено, що на 7, 14 і 21 добу після початку задавання фенбендазолу (II група) суттєвої різниці у вмісті первинних і вторинних продуктів ліпопероксидації у плазмі крові качок дієнових кон'югатів (ДК) і малонового діальдегіду (МДА) не відзначено. Задавання фенбендазолу разом iз добавкою маклеї серцевидної (VI група) призвело до вірогідного зниження концентрації цих продуктів: ДК на 24-25 і 23 \% та МДА - на 24-14 і 6\% відповідно відносно контрольних значень цього показника (табл. 1).

Таблиия 1

Рівень показників інтенсивності процесів ПОЛ у плазмі крові качок у динаміці перорального введення препаратів 3 кормом $(\mathrm{M} \pm \mathbf{m} ; \mathbf{n}=7)$

\begin{tabular}{|c|c|c|c|}
\hline \multirow[t]{2}{*}{ Група качок } & \multirow[t]{2}{*}{ Строки досліджень, доба } & \multicolumn{2}{|c|}{$\begin{array}{c}\text { Інтенсивність ПОЛ, продукти ліпо- } \\
\text { пероксидації }\end{array}$} \\
\hline & & ДК, мкмоль/л & МДА, $\triangle Д$ \\
\hline \multirow{3}{*}{ I група - «контроль» } & 7 & $26,30 \pm 1,00$ & $2,67 \pm 0,26$ \\
\hline & 14 & $24,80 \pm 0,60$ & $2,70 \pm 0,17$ \\
\hline & 21 & $24,67 \pm 0,91$ & $2,58 \pm 0,08$ \\
\hline \multirow{3}{*}{$\begin{array}{l}\text { II група - фебендазол, } \\
50 \text { мг/кг маси тіла }\end{array}$} & 7 & $24,60 \pm 0,37$ & $2,41 \pm 0,03$ \\
\hline & 14 & $23,50 \pm 2,40$ & $2,80 \pm 0,12$ \\
\hline & 21 & $24,30 \pm 1,40$ & $2,56 \pm 0,20$ \\
\hline \multirow{3}{*}{$\begin{array}{l}\text { III група - добавка маклеї серцевидної, } \\
\text { 1,125 г/кг корму }\end{array}$} & 7 & $23,97 \pm 0,70$ & $2,48 \pm 0,08$ \\
\hline & 14 & $24,10 \pm 1,60$ & $2,50 \pm 0,18$ \\
\hline & 21 & $21,50 \pm 0,26^{*}$ & $2,31 \pm 0,16^{*}$ \\
\hline \multirow{3}{*}{$\begin{array}{l}\text { IV група - добавка маклеї серцевидної, } \\
\text { 11,25 г/кг корму }\end{array}$} & 7 & $29,83 \pm 0,70^{*}$ & $3,22 \pm 0,11^{*}$ \\
\hline & 14 & $26,22 \pm 1,50$ & $2,73 \pm 0,08$ \\
\hline & 21 & $25,08 \pm 1,64$ & $2,67 \pm 0,11$ \\
\hline \multirow{3}{*}{$\begin{array}{l}\text { V група - добавка маклеї серцевидної, 0,563 } \\
\text { г/кг корму }\end{array}$} & 7 & $26,60 \pm 0,40$ & $2,57 \pm 0,13$ \\
\hline & 14 & $25,50 \pm 0,80$ & $2,64 \pm 0,08$ \\
\hline & 21 & $23,81 \pm 0,40$ & $2,49 \pm 0,15$ \\
\hline \multirow{3}{*}{$\begin{array}{l}\text { VI група - фенбендазол } 50 \text { мг/кг маси тіла }+ \\
\text { добавка маклеї серцевидної (1,125 г/кг корму) }\end{array}$} & 7 & $21,20 \pm 0,45^{*}$ & $2,15 \pm 0,05^{*}$ \\
\hline & 14 & $19,80 \pm 1,30^{*}$ & $2,35 \pm 0,05^{*}$ \\
\hline & 21 & $20,30 \pm 1,15^{*}$ & $2,43 \pm 0,17$ \\
\hline
\end{tabular}

Примітка: * - різниця значень вірогідна за (P $\leq 0,05)$, відносно значень такого показника у контрольній групі у відповідний термін досліджень (І група). 
У плазмі крові качок III групи, яким задавали лише добавку маклеї в дозі 1,125 г/кг корму, виявляли також зниження утворення токсичних продуктів ПОЛ відносно контрольної групи, але це було вірогідним лише на 21 добу $(\mathrm{P} \leq 0,05)$ після початку досліду та дорівнювало для ДК - 9-2-14\% і для МДА - 7-8-11\% відповідно.

Слід відзначити, що додавання до раціону качок добавки маклеї у вищій дозі (11,25 г/кг корму; IV група) призводило, навпаки, до підвищення вмісту ДК і МДА у плазмі крові на 7 добу експерименту на 13,4 і 20,6\% (Р $\leq 0,05)$ відповідно відносно показників у контрольній групі птиці. У подальші строки досліджень (на 14 та 21 добу) рівень утворення як ДК, так і МДА поступово знижувався відносно початкового (7 доба) та статистично не відрізнявся від такого у контрольній групі.

Встановлено, що у плазмі крові качок V групи, яким згодовували добавку маклеї у підпороговій дозі (0,563 г/кг корму), значення ДК і МДА впродовж експерименту не набували статистичних змін відносно контрольного рівня цих показників.

Кооперативна робота антиоксидантних ферментів $\epsilon$ важливим фактором, який визначає концентрацію продуктів ПОЛ у клітинах організму. Встановлено, що внаслідок задавання фенбендазолу впродовж експерименту в крові експериментальних качок (II група) відбувались зміни показників АОС, як ферментативної, так й не ферментативної її ланок. Так, на 7 добу після початку досліду виявляли вірогідне збільшення активності каталази відносно іiі контрольного рівня на $42,9 \%$, яка за своєю функцією попереджує накопичення у клітинах перекису водню, що утворюється, зокрема, під час дисмутації супероксидного аніону та аеробному окиснюванні відновлених флавопротеїдів. У наступні терміни досліджень, на 14 та 21 добу, іiі активність знижувалась та була нижчою від контрольної групи на 16,1 та $32,4 \%$ (P $\leq 0,01)$ відповідно (табл. 2).

Поряд із цим, слід відзначити, що активність СОД, яка каталізує реакцію дисмутації супероксидних радикалів із утворенням високотоксичного агенту перекису водню, змінювалась у плазмі крові качок II дослідної групи іншим шляхом. Так, спочатку експерименту (на 7 добу) рівень iї активності не змінювався відносно контрольної групи, а у подальшому - на 14 та 21 добу - збільшувався у середньому на 45,1 та 44,5\% (P $\leq 0,05)$ відповідно.

Таблиия 2

Рівень показників функціональної активності АОС у плазмі крові качок у динаміці перорального введення препаратів 3 кормом $(\mathrm{M} \pm \mathbf{m} ; \mathbf{n}=\mathbf{3})$

\begin{tabular}{|c|c|c|c|}
\hline \multirow[t]{2}{*}{ №, група птиці } & \multicolumn{3}{|c|}{ Строки дослідження, доба } \\
\hline & 7 & 14 & 21 \\
\hline \multicolumn{4}{|c|}{ Активність каталази, нмоль $\mathrm{H}_{2} \mathrm{O}_{2} /$ сек мг білка } \\
\hline I група & $97,8 \pm 12,0$ & $102,3 \pm 7,0$ & $100,2 \pm 11,0$ \\
\hline II група & $139,8 \pm 10,3^{*}$ & $85,8 \pm 4,0^{*}$ & $67,7 \pm 3,4^{*}$ \\
\hline III група & $139,62 \pm 13,50 * *$ & $145,40 \pm 3,75^{* *}$ & $148,6 \pm 6,28^{* *}$ \\
\hline IV група & $61,26 \pm 6,15^{*}$ & $62,28 \pm 3,58^{*}$ & $71,13 \pm 3,48^{*}$ \\
\hline V група & $96,3 \pm 4,0$ & $101,3 \pm 3,0$ & $102,8 \pm 1,0$ \\
\hline VI група & $105,9 \pm 10,0$ & $88,5 \pm 3,0 * *$ & $75,3 \pm 8,0^{* *}$ \\
\hline \multicolumn{4}{|c|}{ Активність СОД, од.акт./мг білка } \\
\hline I група & $2,80 \pm 0,12$ & $2,73 \pm 0,07$ & $2,83 \pm 0,06$ \\
\hline II група & $2,68 \pm 0,13$ & $3,96 \pm 0,18^{* *}$ & $4,09 \pm 0,21 * *$ \\
\hline III група & $4,85 \pm 0,16^{*}$ & $5,27 \pm 0,31^{*}$ & $5,19 \pm 0,23 *$ \\
\hline IV група & $1,36 \pm 0,02 * *$ & $1,44 \pm 0,10^{* *}$ & $1,52 \pm 0,05^{* *}$ \\
\hline V група & $3,30 \pm 0,14 *$ & $3,48 \pm 0,09^{*}$ & $3,55 \pm 0,21^{*}$ \\
\hline VI група & $2,92 \pm 0,09$ & $3,62 \pm 0,33 * *$ & $5,82 \pm 0,25 * *$ \\
\hline \multicolumn{4}{|c|}{ Загальна АОА, \% інгібіції } \\
\hline I група & $69,3 \pm 3,5$ & $66,1 \pm 2,3$ & $71,0 \pm 1,8$ \\
\hline II група & $57,9 \pm 1,6^{*}$ & $47,5 \pm 3,6^{*}$ & $51,6 \pm 2,1^{*}$ \\
\hline III група & $87,7 \pm 3,5^{*}$ & $89,5 \pm 3,5^{*}$ & $81,6 \pm 1,4^{*}$ \\
\hline IV група & $86,8 \pm 1,6^{*}$ & $55,3 \pm 2,1^{*}$ & $45,9 \pm 1,3^{*}$ \\
\hline V група & $62,1 \pm 4,3$ & $63,4 \pm 1,8$ & $67,8 \pm 4,6$ \\
\hline VI група & $53,9 \pm 7,0^{*}$ & $67,0 \pm 3,5$ & $79,4 \pm 1,6^{*}$ \\
\hline \multicolumn{4}{|c|}{ Білок загальний , г/дм ${ }^{3}$} \\
\hline I група & $32,00 \pm 2,05$ & $35,00 \pm 2,60$ & $36,00 \pm 1,73$ \\
\hline II група & $38,00 \pm 1,72$ & $38,00 \pm 1,08$ & $43,00 \pm 0,22$ \\
\hline III група & $40,00 \pm 3,33$ & $45,00 \pm 2,70$ & $42,00 \pm 2,60$ \\
\hline IV група & $40,00 \pm 0,33$ & $42,00 \pm 1,05$ & $44,00 \pm 4,77$ \\
\hline V група & $37,00 \pm 1,30$ & $39,00 \pm 0,71$ & $38,60 \pm 2,63$ \\
\hline VI група & $40,00 \pm 0,07$ & $42,00 \pm 0,25$ & $44,00 \pm 4,08$ \\
\hline
\end{tabular}

Примітка. * - різниця значень вірогідна за $(\mathrm{P} \leq 0,05)$, ** - різниця значень вірогідна за $(\mathrm{P} \leq 0,01)$ відносно значень такого показника у птиці групи «контроль» у відповідний термін досліджень (І група). 
Необхідно враховувати, що у клітинах напруження активності ферментативної АОС може частково компенсуватися дією їі не ферментативної ланки, одним iз інтегральних показників якої є загальна антиокислювальна активність (загальна АОА) ліпідів крові, яка забезпечується сумарною збалансованою за складом та наявністю в ній структурних антиоксидантів: глутатіону, стероїдних гормонів, токоферолів, церулоплазміну, Селену, трансферину, які забезпечують знешкодження та детоксикацію продуктів ПОЛ.

Так, отримані результати вказують на те, що внаслідок задавання фенбендозолу качкам II дослідної групи на усіх строках досліджень визначали вірогідне зниження рівня показника загальної АОА ліпідів плазми крові відносно його контрольного рівня, відсоток якого дорівнював у середньому 19,7-39,2-37,6\% відповідно.

Під час додавання до раціону качок добавки маклеї серцевидної у різних дозах (III, IV і V дослідні групи) виявляли іншу динаміку показників AOC.

У випадку задавання маклеї у дозі 1,125 г/кг корму (III група) впродовж експерименту встановили посилення активації обох ланок АОС, а саме: вірогідне збільшення рівня активності обох досліджуваних ферментів та показника загальної АОА. Так, у плазмі крові качок цієї групи на 7, 14 і 21 добу експерименту встановлено підвищення активності каталази на 42,7$42,1-48,3 \%,(\mathrm{P} \leq 0,05)$ та СОД - на 73,2-93,0-83,4\% $(\mathrm{P} \leq 0,01)$ та рівня загальної АОА - на 26,6-35,4$14,9 \%$ (P $\leq 0,05)$ відповідно відносно контрольної групи.

За додавання до раціону качок маклеї у вищій дозі (IV дослідна група), виявили такі зміни: впродовж експерименту встановили гальмування активності обох антиоксидантних ферментів, а саме: відсоток зниження активності каталази і СОД становив на 7 добу - 59,6\% і 2 рази, на 14 добу - на 64,2-89,6\% і на 21 добу - на 40,9-86,2\% (P $\leq 0,01)$ відповідно відносно контрольної групи. Поряд з цим, рівень загальної AOA у плазмі крові качок цієї групи спочатку експерименту (на 7 добу) значно підвищився у середньому на $25,3 \%$, а у наступні строки досліджень - знизився, що становило на 14 та 21 добу відповідно на 19,5\% і $54,7 \%$ (Р $\leq 0,05)$ відносно контрольної групи птиці.

Встановлено, що задавання як добавки до раціону птиці маклеї у зниженій дозі (V група) призводило на усіх термінах досліджень до активації лише СОД в плазмі крові качок, відсоток якої відносно ії контрольних значень становив 18,0\% на 7, 27,5\% - на 14 i $25,4 \%$ - на 21 добу досліджень (P $\leq 0,05)$. У цей час динаміка активності каталази та показника загальної АОА не набувала статистичних змін упродовж усього експерименту, а значення цих показників наближались до їх контрольного рівня.

Одночасне задавання фенбендазолу та добавки маклеї у дозі 1,125 г/кг корму (VI група) до раціону качок на ранніх строках дослідження (7 доба) призводило до вірогідного зниження рівня загальної АОА у плазмі крові птиці на 28,6\% відносно такого у I групі. У цей же час досліджень активність обох ферментів за значеннями була близькою до ії контрольного рівня.
На 14 добу експерименту в плазмі крові качок цієї групи, навпаки, активність каталази почала знижуватись, а активність СОД - збільшуватись відносно іiі контрольного рівня, що становило у середньому $15,6 \%$ і $32,6 \%(\mathrm{P} \leq 0,05)$ відповідно відносно контрольної групи. Поряд з цим, рівень загальної АОА нормалізувався, та за значенням був близьким до контрольної групи.

Наприкінці експерименту (21 доба) у качок VI дослідної групи направленість щодо змін активності ферментів зберігалась подібно попередньої (14 доба) i становила $33,1 \%$ і у 2 рази відповідно (P $\leq 0,01)$, а збільшення рівня загальної АОА відносно контрольної групи у плазмі крові птиці набуло вірогідності відсоток якого дорівнював у середньому $11,8 \%$ (P $\leq$ $0,01)$.

\section{Висновки}

1. Задавання качкам тільки фенбендозолу (II дослідна група), призводить активації процесів ПОЛ i, виходячи 3 характеру їх змін (зниження активності обох антиоксидантних ферментів і AOA) у крові качок можна вважати на те, що потенціалу власних ресурсів АОС організму дослідної птиці виявилось недостатньо.

2. Додавання рослинної добавки маклеї серцевидної у дозі (1,125 г/кг корму) окремо (III група) та одночасно $з$ фенбендазолом (VI група) призводило до індукції антиокиснювальних ресурсів у організмі дослідних качок. Так, у першому випадку зберігання рівнів продуктів ПОЛ в організмі дослідних качок у фізіологічних величинах відбувалось за рахунок індукованої активації обох антиоксидантних ферментів та відновлення пулу ендогенної загальної АОА, а у другому випадку - за зниження до фізіологічної норми активності каталази та компенсаторного посилення активності СОД поряд із ростом загальної АОА.

\section{Бібліографічні посилання}

Garcon, G. (2006). Dunkerque City air pollution particulate matter - induced cytotoxicity, oxidative stress and inflammation in human epithelial lung cells. Toxicol. in vitro. 20(4), 519-529.

Gutyj, B.V., Murs'ka, S.D., Gufrij, D.F., Hariv, I.I., Levkivs'ka, N.D., Nazaruk, N.V., Gajdjuk, M.B., Pryjma, O.B., Bilyk, O.Ja., Guta, Z.A. (2016). Influence of cadmium loading on the state of the antioxidant system in the organism of bulls. Visnyk of Dnipropetrovsk University. Biology, ecology. 24(1), 96-102. doi:10.15421/011611.

Gutyj, B., Lavryshyn, Y., Binkevych, V., Binkevych, O., Paladischuk, O., Strons'kyj, J., Hariv, I. (2016). Influence of «Metisevit» on the activity of enzyme and nonenzyme link of antioxidant protection under the bull's body cadmium loading. Scientific Messenger LNUVMBT named after S.Z. Gzhytskyj. 18, 2(66), 52-58. doi:10.15421/nvlvet6612

Gutyj, B., Paska, M., Levkivska, N., Pelenyo, R., Nazaruk, N., Guta, Z. (2016). Study of acute and chronic toxicity of 'injectable mevesel' investiga- 
tional drug. Biological Bulletin of Bogdan Chmelnitskiy Melitopol State Pedagogical University, 6(2), 174-180. doi: http://dx.doi.org/10.15421/ 201649

Gutyj, B.V., Hufriy, D.F., Hunchak, V.M., Khariv, I.I., Levkivska, N.D., Huberuk, V.O. (2016). The influence of metisevit and metifen on the intensity of lipid per oxidation in the blood of bulls on nitrate load. Scientific Messenger LNUVMBT named after S.Z. Gzhytskyj. 18, 3(70), 67-70 doi: http://dx.doi.org/10.15421/nvlvet7015

Zenkov, N.A., Lankin, V.Z., Men'shikova, E.B. (2001). Okislitel'nyj stress: biohimicheskij i patofiziologicheskij aspekt. M.: Maik (in Russian).

Instruktsiia do zastosuvannia fenbendazolu 5,5\%. - TOV «Ukrvetbiofarm», 2015. (in Ukrainian).

Blinova, K.F., Jakovlev, G.P. (1990). Botanikofarmakognosticheskij slovar'. M.: Vyssh. shk. (in Russian).

Zhukova, I.O., Kostiuk, I.O., Bazdyrieva, N.O., Sobakar, A.V., Kochevenko, O.S. (2016). Dosvid i perspektyvy zastosuvannia maklei sertsevydnoi ta dribnoplidnoi u tvarynnytstvi. Problemy zooinzhenerii ta veterynarnoi medytsyny: Zb. nauk. prats KhDZVA.- Kh.: RVV KhDZVA. 30, 132-135 (in Ukrainian).

Instrukcija po primeneniju Sangrovita Extra dlja uluchshenija poedaemosti kormov i povyshenija produktivnosti sel'skohozjajstvennyh zhivotnyh. Phytobiotics Futterzusatzstoffe GmbH : www.phytobiotics.ru [Elektronnij resurs], 2 (in Russian).

Stehnii, B.T., Kovalenko, L.V., Romanko, M.Ie. (2007). Metody otsinky intensyvnosti perekysnoho okysnennia lipidiv ta yoho rehuliatsii u biolohichnykh obiektakh [Tekst] : metod. Rekomendatsii. Metod. rek-tsii: Zatv. Nauk.-metod. radoiu DKVM, protokol № 1 vid 20 hrudnia 2007 r. - NNTs «IEKVM». Kharkiv, 59 (in Ukrainian).

Gavrilova, V.B., Mishkorudnaja, M.I. (1985). Spektrofotometricheskoe opredelenie soderzhanija gidroperekisej lipidov v plazme krovi. Lab. delo. 3, 33-35 (in Russian).
Koroljuk, M.A. (1988). Opredelenie aktivnosti katalaz. Lab. delo. 1, 16-18 (in Russian).

Klebanov, G.I. (1988). Ocenka antiokislitel'noj aktivnosti plazmy krovi s primeneniem zheltochnyh lipoproteidov. Lab. delo. 5, 59-62 (in Russian).

Khariv, M., Gutyj, B., Butsyak, V., Khariv, I. (2016). Hematological indices of rat organisms under conditions of oxidative stress and liposomal preparation action. Biological Bulletin of Bogdan Chmelnitskiy Melitopol State Pedagogical University. 6 (1), 276289. doi: http://dx.doi.org/10.15421/201615

Lavryshyn, Y.Y., Varkholyak, I.S., Martyschuk, T.V., Guta, Z.A., Ivankiv, L.B., Paladischuk, O.R., Murska, S.D., Gutyj, B.V., Gufriy, D.F. (2016). The biological significance of the antioxidant defense system of animals body. Scientific Messenger LNUVMBT named after S.Z. Gzhytskyj. 18, 2(66), 100-111. doi:10.15421/nvlvet6622.

Martyshuk, T.V., Gutyj, B.V., Vishchur, O.I. (2016). Level of lipid peroxidation products in the blood of rats under the influence of oxidative stress and under the action of liposomal preparation of «Butaselmevit», Biological Bulletin of Bogdan Chmelnitskiy Melitopol State Pedagogical University, 6 (2), 22-27. doi: http://dx.doi.org/10.15421/201631

Nazaruk, N.V., Gutyj, B.V., Murskaja, S.D., Gufrij, D.F., Hariv, I.I., Guta, Z.A., Vishhur, V.Ja. (2016). Vlijanie vitamiksa Se i metifena na sistemu antioksidantnoj zashhity organizma bychkov pri nitratno-kadmievoj nagruzke. Nauchno-prakticheskij zhurnal. Uchenye Zapiski. - Vitebsk, 52(1), 134-138 (in Russian).

Hariv, M.I., Gutyj, B.V. (2016). Influence of the liposomal preparation Butaintervite on protein synthesis function in the livers of rats under the influence of carbon tetrachloride poisoning. Visnyk of Dnipropetrovsk University. Biology, medicine. 7(2), 123-126. doi: 10.15421/021622.

De Bono, D.P. (1994). Free radicals and antioxidants in vascular biology: the roles of reaction kinetics, rnvironment and substrate turnover. Q.J.M. 87(8), 445-453.

Стаття надійшла до редакиії 16.03.2017 